\title{
A Primer on Exporting to Canada 1
}

\author{
Christina D. Storz, Timothy G. Taylor, and Gary F. Fairchild ${ }^{2}$
}

\section{Introduction}

Every year the U.S. Department of State publishes extensive Country Commercial Guides for a large number of countries. These guides provide a great deal of information useful to individuals interested in developing export markets either through direct exports or through direct foreign investment. This paper provides an abridged version of the Country Commercial Guide for Canada as well as supplemental information of direct relevance to agribusiness firms. It is hoped that the information contained in this report provides a useful starting point for individuals interested in exploring export or investment opportunities in Canada.

Note: County Commercial Guides are available for U.S. exporters from the National Trade Data Bank's CD-ROM or via the Internet. Please contact Stat-USA by telephone (1-800) STAT-USA for more information. Country Commercial Guides can be accessed via the World Wide Web at http://www.stat-usa.gov, http://www.state.gov, and http://www.mac.doc.gov. They can also be ordered as a hard copy or on diskette from the National Technical Information Service (NTIS) by telephone (1-800) 553-NTIS. American exporters seeking general export information/assistance and country-specific commercial information should contact the U.S. Department of Commerce, Trade Information Center by telephone (1-800) USA-TRADE; or by fax (202) 482-4473.

\section{Economic and Political Overview}

Canada has a population of roughly one tenth that of the United States; the Canadian economy also mirrors the U.S. economy in about the same ratio. In many respects, the two countries have developed along similar lines. This has made Canada an ideal export and investment destination for American companies looking for an environment and marketplace most similar to their own. Cultural and historical ties and strong awareness of business and technological developments in the United States are also key factors contributing to the enormous volume of sales of U.S. goods and services in the Canadian market. Third-country competition tends to be far less prevalent in Canada than in most other international markets. NAFTA (North American Free Trade Agreement) offers tariff-free benefits for U.S.-produced goods. Add the advantages of congruent time zones, a straightforward regulatory regime, and a common language, makes doing business in Canada good sense.

1. This is EDIS document FE500, a publication of the Department of Food and Resource Economics, Florida Cooperative Extension Service, Institute of Food and Agricultural Sciences, University of Florida, Gainesville, FL. Published February 2005. Please visit the EDIS website at http://edis.ifas.ufl.edu.

2. Christina D. Storz, Research Assistant; Timothy G. Taylor, Professor; and Gary F. Fairchild, Professor, Department of Food and Resource Economics, Florida Cooperative Extension Service, Institute of Food and Agricultural Sciences, University of Florida, Gainesville, FL. 
The Canadian economy grew by $3.3 \%$ in 2002 and is expected to expand by over $2.5 \%$ during 2003. Private consumption is forecast to remain strong in 2003, due primarily to solid real growth in wages and low unemployment. Canada's economy will continue to generate demand for U.S. goods and services of all kinds. American companies should continue to find Canada an extremely attractive and accessible place to do business. In 2002, two-way trade in goods and services between the United States and Canada amounted to US\$432 billion, which was larger than total U.S. trade with the entire 15-country European Union. In fact, the U.S.-Canada trade relationship is the largest economic relationship that has ever existed between two nations.

In general, Canadians have strong national pride and will often favor Canadian products over U.S. products if price and quality are similar. Nevertheless, U.S. firms that can offer technical, cost, or product advantages over locally produced goods can do as well in the Canadian market as they can in the domestic American market. Business opportunities in Canada cover the full range of industrial and agricultural sectors and include virtually every commercial activity. In the agricultural sectors, there will be continued strong demand for fresh vegetables, seafood, snack foods, fruit and vegetable juices, and organic food.

\section{Marketing U.S. Products and Services}

There are a number of factors that should be considered in exporting products to Canada. This section provides a brief overview of many critical factors that must be considered.

\section{Establishing a Business}

Incorporation in Canada is a straightforward and inexpensive procedure, accomplished federally under the Canada Business Corporations Act or provincially under provincial corporate statutes. The major differences between incorporating federally and provincially include the need to publicize financial statements, fees, and turnaround time on the incorporation process. Incorporating federally allows companies to conduct business in any province, although the corporation may still be required to pay a license or registration fee in some provinces.

A flat fee of C $\$ 500$ (approximately US\$365) is charged to incorporate federally. Fee structures vary among the provinces; however, most provinces charge approximately from $\mathrm{C} \$ 200$ to $\mathrm{C} \$ 300$. An average of three to four weeks is required to process an application. Information on incorporating federally under the Canada Business Corporations Act can be obtained from Industry Canada's Corporation Branch.

\section{Distribution / Sales Channels}

Sales to Canadian companies are handled through relatively short marketing channels, and in many cases products move directly from manufacturer to end-user. A large number of Canadian industries are dominated by a handful of companies that are highly concentrated geographically. In many cases, $90 \%$ or more of the prospective customers for an industrial product are located in or near two or three cities. Canada's consumer goods market, on the other hand, is much more widely dispersed than its industrial market. The use of marketing intermediaries in consumer goods is common practice. Often, complete coverage of the consumer market requires representation in the various regions of Canada. Toronto, the largest metropolitan area and commercial center of the country, is usually the most logical location for establishing sole representation. From a regional perspective, the country may be divided geographically into five distinct markets plus the territories which are detailed later in this chapter. Establishing representation in each of these markets provides optimal coverage and the ability to target promotional programs to suit specialized market needs.

\section{Agents / Distributors: Finding a Partner}

Distribution channels in Canada vary greatly according to the products and commodities involved. Large industrial equipment, for example, is usually purchased directly by end-users. In contrast, smaller equipment and industrial supplies are frequently imported by wholesalers, exclusive distributors, or manufacturers' sales subsidiaries. American firms have historically preferred to appoint manufacturers' 
agents who regularly call on potential customers to develop the market.

Many sales agents expect to work on a two-tier commission basis. Agents receive a lower commission for contract shipments and a higher rate when purchases are made from the local agent's own stocks. Consumer goods are purchased by importing wholesalers, department stores, mail-order houses, chain stores, purchasing cooperatives, and multi- and single-line retailers. Manufacturers' agents play an important role in the importation and distribution of consumer goods. In addition, the importance of department stores, mail-order houses, and cooperative purchasing organizations as direct importers has increased substantially. Many of these groups have their own purchasing agents in the United States.

For assistance in identifying appropriate agents and distributors in Canada, U.S. companies are advised to contact the Export Assistance Center serving their area to request the International Partner Search (IPS) or Gold Key Service. To locate the nearest office, please call the U.S. Department of Commerce's Trade Information Center toll-free at (1-800) 872-8723, or check the U.S. Commercial Service's website at http://www.export.gov/cs.

\section{Direct Marketing}

Canadian consumers purchase more goods per capita through the mail than do their U.S. counterparts. Tapping into this market can be as easy as placing an advertisement in a magazine or on the Internet. In general, Canadian audiences are targeted using the same techniques that are used in the United States. However, shipping goods to Canadian customers involves additional preparation.

When mailing goods to Canada, properly completed paperwork will ensure the goods reach their destination without delay. For most mail-order shipments, the only paperwork needed is a standard business invoice. When completing the invoice, two elements are critical: a description of the goods and the value of the goods. Companies should indicate the amount paid by the customer for the goods, in either U.S. or Canadian dollars. Companies shipping goods on a no-charge basis (samples or demos) must indicate the retail value of the shipment. Two copies of the invoice should be attached to the outside of the package.

All goods entering Canada are cleared through Customs, where duties are levied based on the value of the item(s). The type of product and the country of origin determine duties for a specific product. The Customs Act states that, "the validation for duty is the selling price that appears on commercial invoices covering sales in the country of export. This price may include freight, warranty, and other charges applicable in the domestic market of the country of export."

All shipments to Canada are also subject to the 7\% Goods and Services Tax (GST), a multi-stage sales tax. Although companies pay the GST on each purchase, it is recoverable because the GST is a consumer tax, not a business tax. Canada Post also charges a C $\$ 5$ (approximately US $\$ 3.65$ ) processing fee on all packages that owe duty or tax. Mail-order companies can avoid having the $\mathrm{C} \$ 5$ fee assessed to their customers by registering to collect Canadian duties and taxes themselves as a Non-Resident Importer. Companies registering with Canada's Customs and Revenue Agency will be required to prepay duties and taxes monthly. Companies can also arrange to put up a bond in the amount of the estimated duties and taxes.

\section{Franchising}

Canada is one of the largest foreign markets for U.S. franchisers. Canada's franchising sector is made up of approximately 1,300 franchisers and over 80,000 individual units, ranging from restaurants to non-food retail establishments, food and convenience stores, automotive products and services outlets, and purveyors of business services. Annual sales by franchises in Canada total over $\$ 60$ billion, representing about $50 \%$ of all service and retail sales but only $5 \%$ of total businesses.

Franchises have enjoyed exceptional success in Canada. The principal advantage U.S. franchisers have over third-country competitors in this sector is the strong recognition and familiarity of American products and services with Canadian consumers. The high volume of travel by Canadians to the United States combined with constant exposure to U.S. 
television media results in the relatively high receptivity, which most Canadians have to U.S. products and services. Overall, U.S. companies seeking to introduce proven franchise operations supported by sufficient marketing and promotional campaigns can expect to be extremely well-received by Canadian consumers and potential franchisees.

Franchising is an attractive method of doing business in Canada because there are currently no federal regulations that specifically restrict franchise activities. Alberta and Ontario are the only provinces in Canada with legislation regulating franchise operations. These provincial regulations are intended to ensure that small business franchise investors are better able to make informed decisions prior to committing to franchise agreements. For more information, check the Canadian Franchise Association's website at http://www.cfa.ca.

\section{Joint Ventures / Licensing}

Any arrangement in which two or more businesses combine resources for some definable undertaking is considered a joint venture. The Canadian legal system provides great flexibility and imposes few restrictions as to the form that joint ventures may take (e.g., equity or non-equity). Some joint ventures require approval from the government of Canada under the Investment Canada Act. Approval is based on the "net benefit" of the venture to Canada. The "benefit criteria" include the level of Canadian participation, the positive impact on productivity, technological development, product innovation, industrial efficiency, and product variety in Canada. In certain key industries, joint ventures with Canadian partners may prove to be the most effective or, in some cases, the only means of market entry for U.S. companies.

There are a variety of reasons that Canada is an attractive market for foreign licensors. Most notably, Canada has no regulatory scheme governing licensing arrangements. Foreign licensors also do not require registration or public disclosure. Moreover, the Investment Canada Act has no direct application to licensing unless it relates in some way to the control of a Canadian enterprise.

\section{Selling Factors / Techniques}

For first-time exporters to the market, it is important to note that distinct cultural differences between Canada and the United States may in some cases dictate a wholly Canadian approach to selling, advertising, and marketing. Although many strategies used by firms in the United States can be equally effective in the Canadian market, U.S. companies are advised to not automatically assume that selling in Canada is the same as selling in the domestic U.S. market. American companies should carefully research the implications of promotional activities prior to their implementation in Canada.

\section{Advertising / Trade Promotion}

Television advertising accounts for the largest percentage of net ad revenues, followed by advertising in magazines and newspapers. Although a majority of Canadians speak English, the French-speaking areas (concentrated in Quebec) should be considered a distinct market. Quebec is well served by French-language press, radio, and television. Advertising directed toward this market should be specifically tailored to Quebec's distinct cultural identity, consumer tastes, preferences, and styles. Over 600 advertising agencies operate throughout Canada and a number of these are subsidiaries of U.S. companies. Canadian advertising rates are generally comparable with those in the United States.

The Canadian Broadcasting Corporation (CBC) operates both English-language and French-language national television networks. Both networks broadcast on two channels, one with regular programming and one with all-news programming. There are two private national television networks: CTV, broadcasting on two English-language channels (regular programming and all-news) and Global Television, broadcasting on a single English language channel. There are also 105 independent television stations in Canada.

\section{Sales Service / Customer Support}

Canadian companies have a strong awareness of, and preference for, U.S. products and services. Nevertheless, Canadian customers, whether corporate 
or individual, demand high-quality sales service and after-sale customer support, particularly because of the often significant distances involved between customers in Canada and sellers in the United States. Corporate clients often expect the U.S. seller to have an agent or distributor whom they can contact immediately should any problems arise. Like their counterparts in the United States, Canadian customers expect fast service and emergency replacement if required.

An American company entering Canada should evaluate the system of after-sale service and support in the U.S. market, and replicate that network as closely as possible in the Canadian market. If the market demands a strong network of sales and after-sale service in the United States, it is probable that success in Canada will depend on appointing agents who can provide that service. There are many companies in Canada that can offer that service as an agent or representative, or on a retainer basis.

Alternatively, many U.S. companies have found that establishing a toll-free telephone number that services both Canada and the United States is extremely useful in maintaining contact with customers. This gives Canadian customers instant access to U.S. vendors for solving problems, answering questions, or simply providing a higher "comfort level" with a new product.

\section{Product Pricing}

As in the United States, product pricing is key to remaining competitive. In the retail sector, for example, Canadian businesses have followed the successful American trend toward larger stores with highly competitive prices. Retailers in sectors such as food, drugs, consumer electronics, home improvement, office equipment and supplies, and general consumer goods have invested in large discount-style operations to expand sales in an increasingly competitive market. The emergence of high-volume warehouse merchandising in this market is the direct result of consumer demand for competitively priced quality goods. Value for dollar is the predominant purchasing determinant in both the consumer and industrial markets.
When determining appropriate product pricing levels, U.S. firms should pay particular attention to the effects of exchange rates and applicable taxes on the price charged to customers and end-users. A price survey of competitive products available from domestic and third-country sources is an absolute necessity in developing any pricing strategy. Moreover, U.S. firms should be careful not to select pricing levels that may constitute "dumping" or "predatory pricing" infringements under the NAFTA or other international trade agreements.

\section{Selling to the Government}

The U.S.-Canada Free Trade Agreement (FTA) expanded the size of Canada's federal government procurement markets by lowering the threshold for contracts offered by federal entities to as low as $\mathrm{C} \$ 25,000$ (approximately US $\$ 18,250$ ) for goods and C $\$ 100,000$ (US\$73,000) for services and construction. The FTA opened these markets to free, non-discriminatory competition between U.S. and Canadian suppliers. It stipulated clear, fair rules of bid selection and provided for an effective bid challenge system. This meant that a U.S. company bidding on a government of Canada contract could compete on equal footing with its Canadian competitors, and would be judged solely on its ability to deliver a low-cost, high-quality product.

The World Trade Organization Agreement on Government Procurement (WTO-AGP), which came into effect on January 1, 1996, applies to most federal government departments. It is a multilateral agreement that aims to secure greater international competition. The WTO-AGP applies to the procurement of goods and services valued at C $\$ 255,800$ (approximately US $\$ 186,730$ ) or more, and construction requirements valued at $\mathrm{C} \$ 9.8$ million (approximately US\$7.154 million) or more.

The Canadian government's official Internet-based electronic tendering service, MERX, gives subscribers access to more than 1,500 open tenders from the federal government; provincial governments; and many municipalities, school boards, universities, and hospitals. Approximately 200 new tenders are posted daily. American companies can log onto MERX's website at http://www.merx.com free of charge to view and 
search open tenders. Bid documents can then be ordered directly from the website. MERX subscribers, who pay C $\$ 29.95$ (approximately US\$21.90) per month, have access to additional services, such as reduced prices for bid documents, lists of companies that have ordered a particular bid document, and a matching service that informs users of opportunities that fit their predetermined criteria. MERX also has a call center for technical support or general questions, which is available 24 hours a day, seven days a week at 1-800-964-MERX (1-800-964-6379).

\section{Need for a Local Attorney}

The use of attorneys for expediting routine business dealings in Canada is far less prevalent than in the United States, and the tendency to litigate disputes is also less common. Nonetheless, U.S. companies should consult with a local attorney when establishing a corporate investment or other presence, or prior to making contractual commitments related to the marketing of products or services. This requirement becomes even more critical in agreements involving copyright, patent, trademark, or other forms of intellectual property protection.

Most large Canadian law firms have partnerships or strong associations with counterpart firms in the United States and are experienced with international business law. Any legal problems or difficulties with Canadian government agencies are likely to be best handled by an experienced local legal representative. The U.S. Embassy and Consulates in Canada can provide lists of local attorneys experienced in a range of commercial and other legal matters.

\section{Agribusiness Industry Prospects}

American agricultural exports to Canada reached a record-high of US $\$ 8.6$ billion in 2002, registering a robust $7.4 \%$ increase over the previous year. Canada is the largest market for U.S. exports of food and farm products, registering an average annual growth rate above $5 \%$ for the past seven years. American products account for more than two-thirds of total Canadian agricultural imports. Further, the importance of trade with Canadian provinces cannot be underestimated. With regard to agricultural trade, if Ontario, British Columbia, and Alberta were countries, they would rank, respectively, as the 4th (US\$5.1 billion), 9th (US $\$ 1.1$ billion) and 18th (US $\$ 650$ million) largest individual markets for U.S. agricultural exports. Total U.S. agriculture, fish, and forest product exports to Canada in FY2002 (US\$10.8 billion) exceeded the level exported to the 15 European Union member states combined by more than US $\$ 3.0$ billion for the same time period.

Consumer-oriented agricultural products accounted for $70 \%$ of total U.S. food and agricultural product sales to Canada in 2002, with fresh and processed fruits and vegetables, snack foods, and red meat products as the category leaders. American products account for almost two-thirds of total Canadian agricultural imports of US $\$ 12.8$ billion during 2002.

Canada accounted for more than $16 \%$ of total U.S. food and agricultural product exports in 2002 at US $\$ 53.3$ billion. Of total U.S. exports of consumer-oriented agricultural products (US\$21.6 billion), almost $28 \%$ were destined for Canada. Total bilateral agricultural trade between the United States and Canada reached US $\$ 18.8$ billion in 2002, more than US\$50 million per day.

Under the tariff elimination provisions of NAFTA, the majority of U.S. agricultural products have entered Canada duty-free since January 1, 1998. On December 4, 1998, the United States and Canada signed a Record of Understanding, an agreement to further open Canadian markets to U.S. farm and ranch products. Some tangible benefits of the agreement are already accruing to the U.S. agricultural industry.

Trade with Canada is facilitated by proximity, common culture, language, similar lifestyle pursuits, and the ease of travel among citizens for business or pleasure. Many U.S. products have gained an increased competitive edge over goods from other countries as the result of the FTA/NAFTA. Canada's grocery-product and food-service trades have been quick to seize opportunities under FTA/NAFTA, which permit them to expand their geographical sourcing area to include the United States. Declining import duties under the trade agreements and an easing of Canadian packaging requirements for processed horticultural products for the food service 
market have resulted in significant gains in the Canadian market for U.S. consumer-ready foods.

Besides the market opportunities created by reduced tariffs, changing lifestyles in Canada are helping increase the demand for U.S. agricultural products. A decline in real disposable incomes for Canadians throughout the 1990s has led to an increase in dual-income families, which has contributed to a reduction in the number of meals consumed at home. The result has been an increase in imports of U.S. products to meet the demand for high quality, fresh and packaged foods that are ready-to-eat or can be conveniently prepared. In addition, an increasing number of American fast food franchisers operating retail outlets in Canada source food products through U.S. supply channels.

Immigration patterns have changed the face of Canadian cities, where $75 \%$ of Canada's population resides. Immigration in the 1990s was dominated by newcomers of Asian origin, who now account for about $10 \%$ of the population of Canada's two largest cities, Toronto and Vancouver. The combination of the influx of Asian and other ethnic origin immigrants with contrasting dietary traditions and the trend among consumers for a healthier diet has transformed the Canadian food supply. Compared to 20 years ago, Canadians are consuming less sugar, animal fats (including butter and lard), red meat, eggs, canned vegetables, skim milk powder, and alcoholic beverages, while consuming more rice, breakfast cereals, nuts, vegetable-based fats, chicken, fish, fresh vegetables, cheese, yogurt, coffee, and soft drinks.

Canada's wholesale, retail, and food service industries watch with acute interest developments in packaged and processed foods and food service trends in the United States. While there are differences in the consumption patterns of selected food items in the two countries, there is a growing demand in Canada for new value-added foods that are market-proven in the United States.

\section{Agricultural Machinery and Equipment}

Continued low commodity prices over the past five years have had a negative impact on the agricultural machinery and equipment market, but the trend toward diversification of crops and the need to meet worldwide food demand have farmers planting more land and buying more equipment. In 2003, market size exceeded US $\$ 3.7$ billion, with American suppliers meeting roughly one-third of demand. Industry sources predict the sector will grow at a moderate annual rate of between $2 \%$ to $3 \%$. Growth can be attributed to rising worldwide demand as well as decisions by food processing companies to build and expand factories and to introduce new product technologies.

The agricultural machinery and equipment market is highly competitive in terms of price and technology. Companies with significant competitive advantages, such as the latest state-of-the-art technologies and excellent after-sale service, will find good sales and market opportunities in Canada.

\section{Food Service}

Canadian foodservice industry sales reached US $\$ 29.5$ billion during 2002. This includes restaurants; caterers; taverns; and foodservice sales at hotels, institutions, sports stadiums, vending machines, and department stores. There are more than 64,000 foodservice establishments in Canada, of which $66 \%$ are independently owned and operated. Sales of U.S. food products to Canada's food service industry in 2003 are forecast to increase, reflecting similar consumer demand patterns and interaction between U.S. fast-food franchises in Canada and their American raw product suppliers. However, the recent discovery of the livestock disease bovine spongiform encephalopathy (BSE) in Canada and an outbreak of Sudden Acute Respiratory Syndrome (SARS) could result in slower economic activity in the sector while control measures are implemented by Canadian animal and human health officials.

\section{Fresh Vegetables}

American exports of fresh vegetables to Canada reached a record US\$963 million in 2002, more than a $10 \%$ increase over 2001. Canada is the number one market for U.S. exports in this product category. On a per capita basis, Canada has one of the highest consumption rates of fresh vegetables in the world. Increased numbers of meals away from home and wider awareness of healthy eating habits have 
resulted in greater year-round demand in the food service sector for U.S. fresh vegetables. Immigration is dominated by new arrivals from Asia, where traditional dietary habits include large amounts of fresh vegetables. Under the tariff phase-out provisions of NAFTA, U.S. fresh vegetable exports enter Canada duty free. Due to climatic factors in Canada, the domestic growing season for fresh vegetables is short, enhancing Canadian year-round demand for imported fresh vegetables from the United States. A modern transportation and wholesale dealer network provides Canadian buyers with prompt delivery.

\section{Seafood}

American exports of fish and seafood to Canada during 2002 reached US\$574 million, accounting for almost $20 \%$ of total American exports in this category. Canada was the second most important export market for U.S. seafood, after Japan. Per capita fish consumption in Canada is higher than that in the United States and a growing demand for seafood in the retail and food service sectors is expected to boost American seafood sales to Canada to record levels in the coming years.

\section{Snack Foods}

The Canadian retail market for snack foods is valued at approximately US $\$ 2.2$ billion and is growing at a compound annual rate of about $5.8 \%$. Imports from the United States account for $80 \%$ of all snack food imports. There are several significant differences between the Canadian and U.S. snack food markets which any U.S. company that is considering exporting snack food products to Canada must recognize. Key among these is the fact that per capita consumption of snack food is lower in Canada than in the United States, so the Canadian market is somewhat smaller than might be expected based on its population of 31 million. However, since most of the same trends and influences that have generated the increased popularity of snacking in the United States also exist in Canada, Canadian consumers and snack food markets follow U.S. trends but lag slightly behind. The category includes, but is not limited to, potato chips, pretzels, tortilla chips, extruded snacks, nuts, popcorn, snack crackers, baked snacks (e.g., snacking toasts, potato or vegetable thins, portion packs, and snacks to go), cookies, granola and cereal bars. In 2002, Canadian imports of U.S. snack foods reached a record US\$698 million, an increase of $2 \%$ from the previous year.

\section{Fruit / Vegetable Juices}

American exports of fruit and vegetable juices captured about two-thirds of the Canadian import market in 2002, totaling US\$273 million. Canada is heavily dependent on imports of fruit and vegetable juices (fresh and frozen) to meet total market demand. Strong U.S. sales gains have been made in the mixed juice categories. Overall, orange juice is the market leader, with apple and grape sharing about $25 \%$ of total juice sales. Best prospects include the retail market segment, custom retail packaging for Canadian distributors, and new products and blends in new packaging.

\section{Organic Foods}

The annual retail market for organic food in Canada is estimated at between US\$750 million and US $\$ 900$ million, with imports (mostly from the United States), accounting for $80 \%$ of the products sold. The organic market represents approximately $1.5 \%$ of total Canadian retail food sales. Although studies show that only about $18 \%$ of Canadians regularly purchase organic foods, the sector is growing at an average annual rate of over $15 \%$. According to Canadian government sources, $49 \%$ of organic purchases are made in mass-market outlets (supermarkets, drug stores, and mass merchandisers), while $48 \%$ are made in specialty stores. The remaining $3 \%$ of purchases are mostly made at farmers' markets. Canada's agricultural production of organic foods is heavily concentrated in the bulk grains and oilseeds sector. As a result, U.S. exports dominate the packaged organic food market and the fresh produce organic food market. The U.S. organic industry is well poised to capitalize on the increasing demand for organic foods in Canada. 


\section{Trade Regulations and Standards}

\section{Trade Barriers}

As a result of the U.S.-Canada Free Trade Agreement (FTA) that went into effect in January of 1989, virtually all Canadian tariffs on U.S. products have been eliminated. NAFTA, which replaced FTA in January of 1994, removed some remaining barriers and expanded specific provisions of FTA. However, certain non-tariff barriers at both the federal and provincial levels continue to impede access of U.S. goods and services to Canada or retard potential export growth.

\section{Standards}

Though similar, Canada's product standards are not identical to those in the United States. The Canadian government, like the U.S. government, is concerned with protecting its citizens from faulty or unsafe products. However, in delineating the precise technical specifications required to ensure safety, both countries often use slightly different standards.

Under the aegis of the Standards Council of Canada (SCC), several private standards-writing organizations administer technical codes and standards for areas ranging from electrical and plumbing products to health-care technology. These organizations include:

- The Canadian Standards Association (CSA).

- Underwriters Laboratories of Canada (UL).

- The Canadian General Standards Board.

- The Canadian Gas Association.

The Canadian federal government also has numerous commodity standards to safeguard public welfare. The standards organizations try to avoid duplication of responsibility, but there is some overlap.

\section{Labeling Requirements}

Canada requires bilingual labeling (English and French) for most products. The federal Consumer Packaging and Labeling Act requires bilingual designation of the generic name on most prepackaged consumer products. Under this Act, the following information must appear on the package/label of a consumer good sold in Canada:

- Product Identity Declaration: describes a product's common or generic name, or its function. The declaration must be in both English and French.

- Net Quantity Declaration: should be expressed in metric units of volume when the product is a liquid or a gas, or is viscous; or in metric units of weight when the product is solid or by numerical count. Net quantity may be expressed in other established trade terms.

\section{- Dealer's Name and Principal Place of}

Business: states where the prepackaged product was manufactured or produced for resale. In general, a name and address sufficient for postal delivery is acceptable. This information can be in either English or French.

The agency responsible for inspection of imports, Canada Customs and Revenue Agency, also requires an indication of the country of origin, such as "Made in the USA", on several classes of imported goods. Goods not properly marked cannot be released from Canada Customs until suitably marked.

The Province of Quebec requires that all products sold in that province be labeled in French and that the use of French be given equal prominence with other languages on any package or container. The Charter of the French Language requires the use of French on product labeling, warranty certificates, directions for use, public signs, and written advertising.

Finally, industry is charged with ensuring that any claims about a product being "environmentally-friendly" are accurate and in compliance with relevant legislation. In general, environmental claims that are ambiguous, misleading, or irrelevant, or that cannot be substantiated should not be used. In all cases, environmental claims should indicate whether they are related to the product itself or to the product's packaging materials. The Canadian government has issued a set of guiding principles governing the use 
of environmental labeling and advertising, which may be obtained by contacting Industry Canada.

\section{Import Controls}

A properly completed Canada Customs Invoice or its equivalent is required for all commercial shipments exported to Canada. In addition, a completed NAFTA Certificate of Origin must accompany shipments of U.S.-produced goods to obtain tariff-free treatment under the provisions of NAFTA. For further information, contact the Canada Customs and Revenue Agency representative at the Canadian Embassy in Washington, D.C. (telephone 202-682-1740; fax 202-682-7689).

Under NAFTA, most U.S. products shipped to Canada enter the market free from any tariffs or import restrictions. However, under the provisions of the Canadian Customs tariff regulations, certain commodities (e.g., reprints of Canadian copyrighted work) cannot be imported. Other items are regulated under the Export and Import Permits Act and require a permit for importation into Canada. The Act lists various agricultural products (poultry, eggs, and dairy products), a number of textile and clothing items, and certain steel products. Inquiries regarding the issuance of import permit and quota allocations should be directed to the Department of Foreign Affairs, Export and Import Controls Burea in Ottawa concerning agricultural products (telephone 613-995-2744).

\section{Export Controls}

Canada controls exports under authorization of the Export and Import Permits Act (EIPA). The EIPA establishes two export lists: the Export Control List (ECL), which lists specific products that are subject to export restrictions to specified countries, and the Area Control List (ACL), which lists those countries to which all exports are subject to restrictions. The ECL contains a list of products designated as being of strategic military or industrial value, as well as other products included for purposes of conservation (such as endangered species) or trade agreement monitoring (such as steel products). The ECL specifies that export permits do not have to be obtained when the goods and technology listed are being exported to the United States. The exceptions to the general exemption for U.S.-bound shipments are atomic energy materials, various endangered species, and certain forestry products.

Under a bilateral arrangement with the United States, export permits are not required for most ECL items when shipping goods to a final destination in the United States. However, if the ECL goods are only transiting the United States for export to other destinations, an export permit is required. For further information, including which items require permits for export to the United States, contact the Export Controls Division of the Department of Foreign Affairs and International Trade in Ottawa (telephone 613-996-2387; fax 613-996-9933).

\section{Free Trade Zones / Warehouses}

With the exception of one special trade zone at the Sydport Industrial Park in Cape Breton, Nova Scotia, Canada has no free ports or free trade zones. At present, there are no federal or provincial laws specifically governing the establishment and operation of such zones.

Goods may be cleared at Customs offices on the border or may be forwarded to a bonded warehouse for storage, pending Customs examination and clearance. Goods may be sent to a bonded warehouse without the payment of duty, but must be cleared either for export or Canadian consumption within two years. Extended periods are allowed for certain goods.

Goods taken from bonded warehouses for consumption are dutiable at rates of the Customs Tariff in effect at the time, and the value for duty purposes is the value at the time of entry for warehousing. Goods exported from bonded warehouses to third countries are subject to Canadian export regulations. Minor operations such as repackaging and sorting can be carried out in bonded warehouses with the permission of the Canada Customs and Revenue Agency, but assembly or other industrial activity is prohibited.

\section{Membership in Free Trade Agreements}

The U.S.-Canada FTA, implemented in 1989, vastly expanded opportunities for U.S. exporters and investors in Canada. As a result of FTA and the 1994 
NAFTA, trade barriers came down, investment rules were liberalized, and bilateral cooperation on a wide range of issues was expanded. Like the United States, Canada is a member of the WTO, and was a founding member of its predecessor, the General Agreement on Tariffs and Trade (GATT). Canada has also been an active member of both the Asia-Pacific Economic Cooperation (APEC) forum and the Free Trade Area of the Americas (FTAA) negotiation process.

Canada and Israel implemented a bilateral FTA at the start of 1997 that is similar to the U.S.-Israel FTA, but does not deal with government procurement. Canada and Chile implemented a bilateral FTA in mid-1997. This FTA was explicitly designed to facilitate Chile's eventual accession to NAFTA, and includes parallel agreements on environmental protection and labor standards. It immediately eliminates Chile's $11 \%$ duty on most industrial and resource-based exports from Canada, and commits the two countries to eliminating the use of trade remedy laws against each other's firms within six years. Canada and Costa Rica signed a bilateral FTA in 2001. Canada is currently negotiating an FTA with four other Central American countries (Guatemala, Honduras, Nicaragua, and El Salvador) and is contemplating negotiations with the Caribbean Community (CARICOM).

\section{Investment Climate in Brief}

- With few exceptions, Canada offers foreign investors full national treatment within the context of a developed open market economy operating with democratic principles and institutions. Canada is, however, one of the few Organisation for Economic Co-operation and Development (OECD) countries that still has a formal investment review process, and foreign investment is prohibited or restricted in several sectors of the economy.

- Since 1985, foreign investment policy in Canada has been guided by the Investment Canada Act (ICA), which replaced the more restrictive Foreign Investment Review Act. The ICA liberalized policy on foreign investment by recognizing that investment is central to economic growth and is the key to technological advancement.
- The Investment Canada Act is intended to regulate foreign investment in Canada. Investment Canada, the federal regulatory agency under the purview of Industry Canada, only reviews two types of proposed acquisitions when it is deemed that the review is in the public interest. The first type is the direct or indirect acquisition by a foreigner of an existing Canadian enterprise of substantial size. The second type is the acquisition of an existing Canadian enterprise or the establishment of a new Canadian enterprise by a foreigner engaging in business relating to Canada's cultural heritage or national identity.

- American foreign investment in Canada is subject to the Investment Canada Act, but NAFTA further defines the investment relationship between the two countries and adopts the principle of national treatment. The basic obligation assumed by the two countries in Chapter Eleven of NAFTA is to ensure that future regulation of Canadian investors in the United States, and of U.S. investors in Canada, results in treatment no different than that extended to domestic investors within each country ("national treatment").

- Regarding fishing, foreigners can own only $49 \%$ of companies that hold Canadian commercial fishing licenses.

- Regarding real estate, primary responsibility for property law rests with the provinces. Prince Edward Island, Saskatchewan, and Nova Scotia all limit real estate sales to out-of-province parties. There is no constitutional protection for property rights in Canada. Consequently, property can be expropriated by government authorities, but appropriate compensation must be paid.

- Private property rights are fully protected by Canada's legal system. Foreigners have full and fair access to Canada's legal system.

- Canada's regulatory system is similar to that of the United States in terms of its transparency and broad array of institutions involved. 
- The Canadian dollar is fully convertible. The Canadian government provides some incentives for Canadian investment in developing countries through the Canadian International Development Agency (CIDA) programs.

\section{Business Customs}

\section{Travel Advisory and Visas}

Citizens or legal permanent residents of the United States are not required to have entry visas and can usually cross the border between the United States and Canada with minimal difficulty or delay. To expedite border crossings, native-born U.S. citizens should carry either a passport or a birth certificate and photo ID (e.g., a driver's license).

\section{Business Infrastructure}

Business customs in Canada closely mirror those of the United States. This is not to say, however, that doing business in Canada is exactly the same as doing business in the United States. American business travelers to Canada should be sensitive to cultural and linguistic differences and allow adequate time for the development of personal contacts in business dealings.

\section{Useful Web Sites}

\section{CANADA:}

- American Chamber of Commerce http://amchamcanada.ca

- Canadian Embassy of the United States http://www.canadianembassy.org

- Doing Business in Canada http://www.dbic.com

- FTD-US Trade with Canada in 2001 http://www.census.gov/foreign-trade/sitc1/2001/ c1200.html

- CIA Factbook-Canada http://www.cia.gov/cia/publications/factbook/ geos/ci.html

\section{UNITED STATES:}

- USDA Foreign Agricultural Service http://www.fas.usda.gov
- Small Business Administration Export Express http://www.sba.gov/OIT

- US Export Information Center http://www.export.gov

- Basic Guide to Exporting http://www.unzco.com/basicguide/index.html

\section{HEMISPHERIC:}

- Hemispheric Guide on Customs Procedures http://alca-ftaa.iadb.org/hgcp_eng.htm

- Hemispheric Trade and Tariff Database http://alca-ftaa.iadb.org/eng/ngmadb_e.htm 